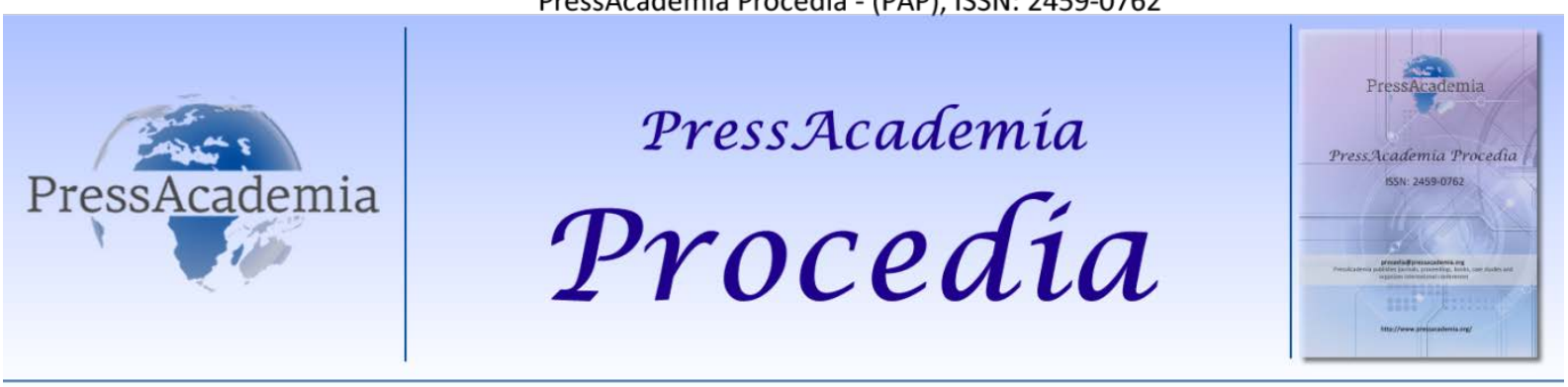

Global Business Research Congress (GBRC), May 26-27, 2016, Istanbul, Turkey.

\title{
PERCEPTIONS OF OPTICAL STORE EMPLOYEES IN THEIR BUSINESS MOTIVATION: THE CASE OF IZMIR
}

\section{DOI: 10.17261/Pressacademia.2016118660}

\author{
Nezih Metin Ozmutaf ${ }^{1}$, Elif Aktekin ${ }^{2}$ \\ ${ }^{1}$ Izmir Katip Celebi University, nezih.metin.ozmutaf@ikc.edu.tr \\ ${ }^{2}$ Ege University, elif.aktekin@ege.edu.tr
}

\begin{abstract}
The main aim of this research is to determine perceptions of optical store employees within the scope of opticianry graduate and non opticianry graduate in their business motivation. The questionnaire prepared on this subject was applied between January 2015 - June 2015 to the 103 (30 opticianry graduate, 73 non opticianry graduate) optical store employees in Izmir. Within the scope of the research, it is expected that there is a correlation between the administrative applications in the optical stores and the business motivation of the optical store employees. These administrative applications that are adequate wage level, adequate benefits, adequate wage increase, unity of purpose, balance of authority and responsibilities, giving the initiative, to appreciate and financially reward, respectful behavior, ensuring the vocational training and development, provision of leadership, increase in provision charges based on performance, emphasis on employee health and safety, improving and increasing employee relations communications, increase the motivation level of employees in optical stores. If otherwise, the motivation level can be neutral or decrease. At the end of the research, it is found that four factors; personal rights (f1), supporting employees I (f2), supporting employees II (f3), employee relations (f4), effects business motivations in the positive way. These four factors affect the opticians' business motivation in the positive way more than non-optician employees. Also four factors have positive correlations at the medium-high level with each other.
\end{abstract}

Keywords : Optical store employees, business motivation

JEL Codes : M12, M54

\section{OPTIK MAĞAZALARINDA ÇALIŞANLARIN IŞ MOTIVASYONUNA YÖNELIK ALGILARI: IZMIR ILI ÖRNEĞi}

\section{ÖZET}

Araştırmanın temel amacı, İzmir ilinde yer alan optik mağazalarındaki optisyenlik bölümü mezunu olan ve meslek içinden gelen çalışanların iş motivasyonlarını etkileyen faktörlere yönelik algılarının belirlenmesidir. Bu kapsamda hazırlanan anket formu Ocak 2015 - Haziran 2015 tarihleri arasında İzmir ilinde yer alan 42 optik mağazasında 103 çalışana (30 optisyenlik bölümü mezunu ve 73 meslek içinden gelen) uygulanmıştır. Verilerin istatistiksel analizi SPSS programında yapılmıştır. Araştırma modelinde, Optik mağazalarındaki yönetsel uygulamalarla, çalı̧̧anların iş motivasyonu arasında ilişkisellik ön görülmüştür. Yeterli ücret düzeyi, yeterli yan ödeme, yeterli ücret artı̧̧ı, amaç birliği, yetki ve sorumluluk denkliği, inisiyatif verme, maddi ve manevi ödüllendirme, saygılı davranma, mesleki eğitim verilmesi ve gelişim sağlanması, liderliğin sağlanması, performansa dayalı ücret artışı sağlanması, çalışan sağlığı ve iş güvenliğine önem verilmesi, iletişim etkinliğinin artıııması ve çalışan ilişkilerinin iyileştirilmesi sonucunda optik mağazalarında çalışanların motivasyon düzeylerinde artı̧̧ sağlanacağı düşünülmüştür. Model kapsamında aksi durumda ise motivasyonun nötr olacağı ya da azalacağı öngörülmektedir.Araştırma sonucunda oluşan 4 faktör; "f1: özlük hakları, f2:çalışanı destekleme I, f3: çalışanı destekleme II, f4: çalışan ilişkileri" kapsamında, katılımcıların iş motivasyonunun ileri düzeyde pozitif olarak etkilendiği algısına sahip oldukları belirlenmiştir. Bu dört faktörün Optisyenlik bölümü mezunlarının, meslek içinden gelenlere göre iş motivasyonlarını pozitif yönde etkilemede daha fazla etkili olduğu, bununla birlikte dört faktörün de birbirleriyle pozitif yönde orta-yüksek düzeyde ilişki içinde oldukları ortaya konmuştur.

Anahtar Kelimeler: Optik mağazası çalışanları, iş motivasyonu JEL Kodları: M12, M54 


\section{GiRiş}

İnsan unsuru, bir örgütte temel yapı taşıdır. Çalışanlar, aldıkları ücret karşılığında emeklerini örgüte aktaran bireyler olmanın ötesinde, birbirleriyle ve örgütle etkileşen önemli üretim faktörlerindendir. Çalışanların yaşam kalitesinin arttırıması, birey ihtiyaçlarının karşılanmasıyla birlikte, örgütün amaçlarına ulaşımasını sağlayacak etkiye sahiptir. Insan odaklı bu anlayış, çalışanların yüksek düzeyde motive olmalarını, işlerine daha rahat konsantre olmalarını ve sonucunda örgüte yapılan katkının arttırılmasını sağlamaktadır (Eren, 1997: 97)

Çalışanların örgütsel amaçlar doğrultusunda çalışmaları, bilgi, yetenek ve güçlerini bu doğrultuda harcamaları, yönlendirici bir güç olan motivasyonla sağlanabilmektedir. Motivasyonda temel amaç, iş görenlerin istekli, verimli ve etkili çalışmasını sağlamaktır. Dolayısıyla insan faktörünün ön planda olduğu sağlık işletmelerinde de çalışanları motive edecek yönetsel faaliyetler oldukça önemlidir. Rahat ve güvenli bir çalışma ortamı sağlanması gibi fiziksel faktörler, ücret düzeyi, prim, ödül gibi ekonomik faktörler, etkin iletişim, inisiyatif ve yetki verme, kararlara katılım, gelişim ve kariyer olanakları sağlama gibi yönetsel faktörler çalışanların iş motivasyonlarını arttıran örgütsel uygulamalardır.

Optik mağazalar koruyucu göz ve görme sağlığı alanında hizmet veren, nitelikli ürünlerle birlikte uzmanlık gerektiren hizmetlerin sunulduğu işletmelerdir. Bu tür işletmelerde çalışan personelin iş performansı, verilen hizmetin kalitesini doğrudan etkilemektedir. Sağlık hizmeti veren personelin iş performansı da uzmanlığı ve deneyimi ile doğrudan ilişkilidir. Motivasyonun çalışanların iş performansını arttıran bir güç olması bağlamında, araştırmamızda Türkiye'deki optik mağazalarda çalışan personelin optisyenlik alanında eğitim alma durumu göz önünde bulundurularak iş motivasyonları değerlendirilmiştir.

Çalışmanın literatür bölümünde motivasyon kavramı ve motivasyon faktörleri ile optik mağazalarında çalışanların uzmanlığı ile mesleki yetki durumu hakkında bilgi verilmiştir. Konu ile ilgili oluşturulan araştırma modeli ve hipotezler ortaya konarak araştırmadan elde edilen verilerin analiz sonuçları yorumlanmıştır.

\section{LITERATÜR TARAMASI}

\subsection{Motivasyon}

Motivasyon "harekete geçmek" anlamına gelen Latince "movere" kelimesinden türetilmiştir. Motivasyon kısaca "belirli bir amaç doğrultusunda bireylerin kendi arzu ve isteklerine göre davranmaları"(Koçel,2001:154) olarak tanımlanmıştır. Yazında yer alan motivasyon tanımlarındaki ortak noktalar; amaca yönelik, harekete geçirici, hareketi devam ettirici, davranışı olumlu yöne sevk ettirici olmasıdır (Eren, 1998:398).

Birey amaca ulaştığı ölçüde mutlu, aksi durumda huzursuz ve isteksiz olmaktadır. Motivasyonun amacı çalışanların daha fazla çalışma istek ve arzusu oluşturabilecek faktörleri bulmak ve bunları mümkün olduğunca karşılamaya çalışmaktır. Motivasyon faktörleri bireysel ihtiyaçların çeşitliliği ve karmaşıklığı nedeniyle sürekli olarak gözden geçirilmeli ve kişiselleştirilmelidir (Karakaya ve Ay, 2007). Örgütler gibi çalışanlar da zamana bağlı olarak değişir. Bu da, motivasyon kaynaklarının değişmesine sebep olur. Bu bağlamda motivasyonun bir süreç olarak ele alınması yöneticilere iş gören motivasyonunun sağlanması veya yükseltilmesi için önemli ipuçları vermektedir (Özdemir, 2008). Eroğlu (1995:247), motivasyon sürecinde davranışın altında yatan faktörlerin (ihtiyaç, beklenti, amaç) uyarılmasının, bireyleri harekete geçirdiğini belirtmiştir. Dolayısıyla motivasyon sürecinde aksama olursa davranışlar farklılaşır ve problemler ortaya çıkabilir. Bu değişim ve farklılaşma da motivasyon dinamiğini yansıtır. Tatmin edilmekte olan bir ihtiyacın ya da isteğin yarıda kalması durumu bile davranışın değişmesine neden olmaktadır (Genç, 1990: 17). Motivasyonun Koçel'in belirttiği iki temel özelliği; kişisel olması ve ancak insan davranışında gözlenebilmesi de motivasyonel süreci desteklemektedir (Koçel, 2001:154).

Motivasyon faktörleri, araştırmalarda farklı niteliklere ve bakış açılarına göre değişik biçimlerde sınıflandırımaktadır. Çalışmamızın kapsamına da uygun olarak bir çok araştırma sonucunda ortaya konmuş maddi ve manevi motivasyon araçları üç grupta toplanabilmektedir; "Ekonomik araçlar, psiko-sosyal araçlar ve örgütsel/yönetsel araçlar" (Eren, 2001).

“Ekonomik araçlar: Ücret artışı, kâra katılma, ekonomik ödül, prim, sosyal yardımlar/kolaylıklardır (daha iyi çalışma ve yaşama olanağı sağlayan ekonomik yararlar; servis, öğle yemeği, çay-kahve servisi, özel sağlık sigortası, giyecek yardımı vb)." 
“Psiko-sosyal araçlar: Çalışmada bağımsızlık, sosyal statü ve katılım, takdir edilme, gelişme ve başarı, çevreye uyum, öneri sistemleri, üstlerle doğrudan görüşme, psikolojik güvence, sosyal faaliyetler, yetki devri, danışmanlık hizmetleridir."

“Örgütsel ve yönetsel araçlar: Amaç birliği, yetki ve sorumluluk dengesi, eğitim, kararlara katılma, iş güvencesi, iletişim sistemi, işi çekici kılma, iş genişletme, iş zenginleştirme, iş rotasyonu, ekip çalışması, müzik eşliğinde çalışma, fiziksel koşulların iyileştirilmesi, terfi ve kariyer geliştirme olanakları, açık yönetim politikası, adaletli ve sürekli disiplin sistemi vb."

\subsection{Optik Mağazası Çalışanları Ve İş Motivasyonu}

Türkiye'deki optik sektörünün perakende bölümünü oluşturan optik mağazalar 2004 yılından beri yürürlükte olan Optisyenlik Hakkında kanun hükümlerine bağlı olarak faaliyetlerini sürdürmektedirler. Yine bu kanunun hükümlerine göre optik mağazalar optisyenlik bölümü mezunu kişilerin sorumluluğunda sağlık hizmetleri ile ilgili faaliyetlerini gerçekleştirebilirler. 1992 yılına kadar Sağlık Bakanlığının açtığı kurslarda başarılı olan kişilerce icra edilen meslek, yükseköğretimde ön lisans seviyesinde optisyenlik eğitiminin düzenlenmesiyle akademik bir kimlik kazanmıştır. 1994 yılından itibaren optisyenlik bölümlerinden mezun olan optisyenler, yeni kanunun yürürlüğe girdiği 2004 yılına kadar mesleklerini icra etme hak ve yetkisine sahip olamamışlardır. Bunun nedeni 1940 yılında düzenlenmiş ve 2004 yılına kadar yürürlükte olan eski kanunun güncel koşullara uygun düzenlemeye sahip olmamasıdır. Bu durum sektör çalışanlarının usta-çırak ilişkisi ile yetişmesini gerektirmiş, mesleği icra etme yetkisi de sağlık bakanlığının belirli dönemlerde düzenlediği kurslar ve sonucunda yapılan sınavlarda başarılı olmaları neticesinde kazanılmıştır. Bu bağlamda optik mağazalarda çalışanların bir bölümünün uzmanlık bilgisi, yeterlilikleri sektörün içinde edindikleri deneyimlerden ve kurslardan, bir bölümünün ise alanları ile ilgili aldıkları eğitimden oluşmaktadır.

Sağlık hizmetleri işletmelerinde verilen hizmetin niteliğinin ana unsuru insan kaynağıdır. Yazında sıklıkla ifade edildiği üzere, personelin iş motivasyonu performansı ile doğrudan ilişkilidir. Bir çalışanın yeterli ücret alabilmesi kadar niteliklerine uygun bir görevde ve iş ortamında çalışması da performansı ile doğrudan ilişkilidir. (Kaplan, 2007). Bir gruba üye olmak, iyi bir görevde çalışmak, yükselmek, eğitilmek, tanınmak, çalışma arkadaşları tarafından kabul edilmek gibi sosyal ihtiyaçlar bireyin kendini gerçekleştirme ihtiyacını karşılayarak iş motivasyonunu arttırmaktadır. Bununla birlikte bireylerin ruhsal yapısı ve farklı düşünme biçimleri nedeniyle psikolojik ihtiyaçlarının anlaşılması kolay değildir. Bireylerin hangi hareketi hangi ihtiyacından dolayı sergilemiş olduğunu kestirmek ruhsal motivlerin uygulanmasını da zorlaştırabilmektedir (Eren, 2001).

\section{VERI VE YÖNTEM}

\subsection{Veri Toplama Araçları}

Araştırma için hazırlanan anket formu iki temel bölümden oluşmaktadır. Birinci bölümde, araştırmanın bağımsız değişkenleri olan yaş, cinsiyet, eğitim durumu, optisyenlik kapsamında eğitim, mesleki çalışma süresi ve genel olarak işteki motivasyon düzeyi şeklinde 6 soru yer almaktadır. Anketin ikinci bölümünde optik mağazalarında yer alan personelin iş motivasyonunu pozitif yönde etkileyebileceği varsayılan 16 önerme yer almıştır. Önermelere istatistiksel değerlendirmeler için 5'li Likert ölçeği kapsamında kesinlikle katılmıyorum için 1, katılmıyorum için 2, fikrim yok için 3, katılıyorum için 4, kesinlikle katılıyorum için 5 ağırlık değeri verilmiştir. 12 önerme faktör analizi sonucu 4 faktör altında toplanmıştır.

\subsection{Verilerin Toplanması Ve Analizi}

Araştırmaya yönelik olarak hazırlanan anket formu İzmir ilinde yer alan 42 optik mağazanın çalışanlarına yüz yüze anket yöntemi ve e-mail yoluyla Ocak 2015 - Haziran 2015 tarihleri arasında uygulanmıştır. İzmir ilinde yer alan optik mağaza sayısı 481 'dir. Bu işletmelerin çalışan sayısına yönelik resmi verilere ulaşılamamakla birlikte mesleki örgütün verdiği tahmini sayı 1200'dür (EGOF, 2014). Anketlerin cevaplanmasıyla ilgili 42 optik mağazadaki 103 çalışandan geri dönüş alınmıştır. Anketlerin tamamı analizlere dâhil edilmiştir.

Araştırmada istatistiksel analizler kapsamında SPSS yazılımı kullanılmıştır. Araştırma kapsamında faktör analizi, evren ortalamasına dayalı $t$ testi, bağımsız iki örnek $t$ testi ve korelasyon analizi gerçekleştirilmiştir. 


\subsection{Araştırmanın Teorik Modeli}

Araştırmanın teorik modeli, optik mağazalarındaki yönetsel uygulamaların çalışanın motivasyon düzeyini etkilediği varsayımı üzerine kurulmuştur. Diğer bir ifadeyle modelde; optik mağazalarındaki uygulamalar kapsamındaki tutum ve davranışlarla çalışan motivasyonu arasında ilişkisellik ön görülmüştür (Bkz. Şekil 1).

Şekil 1: Araştırmanın Teorik Modeli

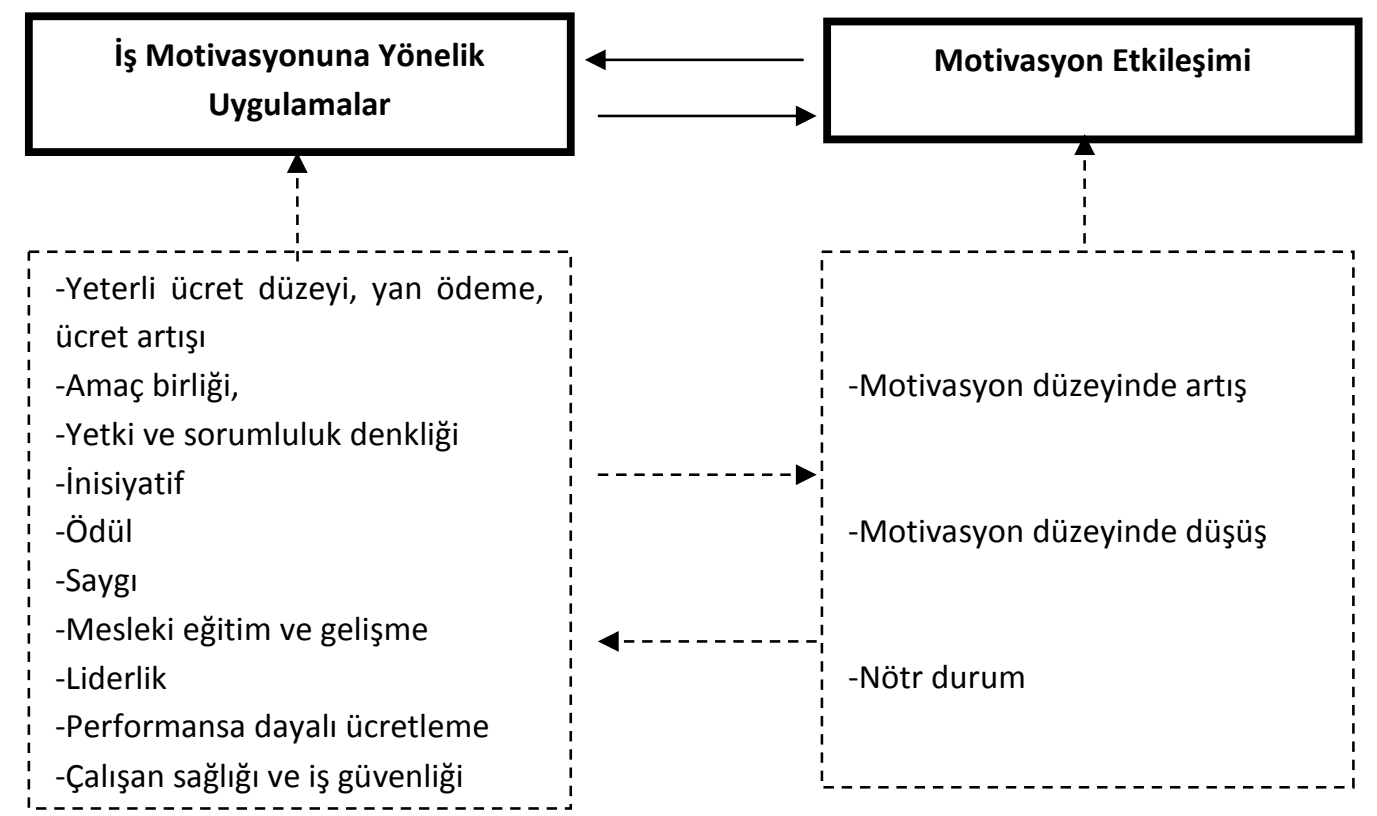

Şekil 1'e göre yeterli ücret düzeyi, yeterli yan ödeme, yeterli ücret artışı, amaç birliği, yetki ve sorumluluk denkliği, inisiyatif verme, maddi ve manevi ödüllendirme, saygılı davranma, mesleki eğitim verilmesi ve gelişim sağlanması, liderliğin sağlanması, performansa dayalı ücret artışı sağlanması, çalışan sağlığı ve iş güvenliğine önem verilmesi, iletişim etkinliğinin artırılması, çalışan ilişkilerinin iyileştirilmesi sonucunda optik mağazalarında çalışanların motivasyon düzeylerinde artış sağlanacağı düşünülmüştür. Model kapsamında aksi durumda ise motivasyonun nötr ya da düşüşü görülebilecektir.

\subsection{Araştırmanın Hipotezleri}

$\mathbf{H}_{1}$ : Optik mağazalarında ... faktörü iş motivasyonunu etkilemede pozitif yönde etkilidir.

$\mathbf{H}_{2}$ : Optik mağazalarında ... faktörü açısından iş motivasyonunu etkilemede optisyenlik bölümü mezunları ile meslek içinden gelenler arasında algı farklılığı vardır.

$\mathbf{H}_{3}$ : Optik mağazalarında iş motivasyonunu pozitif yönde etkileme kapsamında ... faktörleri arasında pozitif yönde doğrusal bir ilişki vardır.

\section{BULGULAR VE TARTIŞMA}

\subsection{Sosyo-Demografik Bulgular}

Araştırmaya katılanların ( $n=103$ ) genel yaş (min-max=19-69) ortalaması ve standart sapması $31,84 \pm 9,11^{\prime}$ dir. Ankete katılan optisyenlik bölümü mezunlarının $(n=30)$ yaş ortalaması ve standart sapması $28,1 \pm 9,88$; meslek içinden gelenlerin $(n=73)$ yaş ortalaması ve standart sapması $32,7 \pm 8,49^{\prime}$ dur.

Meslek içinden gelen personel açısından kadın ve erkek oranı daha yüksektir (Tablo 1). Doğal olarak optisyenlik bölümü mezunları üniversite (ön lisans ya da lisans tamamlama) ve lisansüstü eğitim düzeyinde yer almakta iken meslek içinden gelen personel çeşitli eğitim seviyelerindedir (Tablo 1). Meslek içinden gelen personelin 
çalışma yılı daha fazladır (Tablo 1). İşteki motivasyon düzeyi algısı meslek içinden gelen personelde daha yüksek düzeydedir (Tablo 1).

Tablo 1: Örneklem Profili

\begin{tabular}{|c|c|c|c|c|c|c|c|}
\hline CINSIYET & $\begin{array}{l}\text { OPT. BÖL. } \\
\text { MEZ. (\%) }\end{array}$ & $\begin{array}{c}\text { MESLEK } \\
\text { içiNDEN } \\
\text { GELME (\%) }\end{array}$ & TOPLAM & $\begin{array}{l}\text { ÇALIŞMA } \\
\text { SÜRESI (YIL) }\end{array}$ & $\begin{array}{l}\text { OPT. BÖL. } \\
\text { MEZ. (\%) }\end{array}$ & $\begin{array}{c}\text { MESLEK } \\
\text { IÇiNDEN } \\
\text { GELME (\%) }\end{array}$ & TOPLAM \\
\hline Kadın & 17,5 & 24,3 & 41,7 & $=<5$ & 21,4 & 22,3 & 43,7 \\
\hline Erkek & 11,7 & 46,6 & 58,3 & $6-10$ & 1,9 & 18,4 & 20,4 \\
\hline \multirow[t]{2}{*}{ Toplam } & 29,1 & 70,9 & 100 & $>=11$ & 5,8 & 30,1 & 35,9 \\
\hline & & & & Toplam & 29,1 & 70,9 & 100 \\
\hline EĞітіM & & & & $\begin{array}{l}\text { işTEKI MOTIV. } \\
\text { DÜZEYi }\end{array}$ & & & \\
\hline ilk-orta & 0 & 6,8 & 6,8 & Yüksek & 23,3 & 40,8 & 64,1 \\
\hline Lise & 0 & 36,9 & 36,9 & Orta & 5,8 & 26,2 & 32 \\
\hline Üniv. & 25,2 & 26,2 & 51,5 & Düşük & 0 & 3,9 & 3,9 \\
\hline L. üstü & 2,9 & 1,0 & 3,9 & Toplam & 29,1 & 70,9 & 100 \\
\hline Toplam & 29,1 & 70,9 & 100 & & & & \\
\hline
\end{tabular}

\section{2. Ölçüm Aracının Güvenirliği}

Anketin ikinci bölümünde yer alan 16 önerme temel bileşenler analizi çerçevesinde gerçekleştirilen faktör analizi sonucunda 4 faktör altında toplanmıştır. Kaiser-Meyer-Olkin değeri 0,856'dır. Bartlett Küresellik Testi sonucunda sıfır hipotezi $\left(H_{0}\right.$ : korelasyon matrisi birim matristir) reddedilmiştir $\left(\chi_{120}^{2}=781,006, p=0.000\right)$. Anti imaj korelasyon matrisinin köşegen değerleri 0,937-0,713 değerleri arasında değişim göstermektedir. Bu üç sonuç kapsamında 16 önermelik yapının faktör analizine uygun olduğu belirlenmiştir (Tablo 2). Faktör analizi sonucu oluşan 4 faktör toplam varyansı \%65,447 oranında açıklamaktadır. Toplam varyansın, \%17,730’unu birinci, \%17,557'sini ikinci, \%15,787'sini üçüncü ve \%14,403'ünü dördüncü faktör açıklamaktadır. Oluşan 4 faktörlük yeni yapının genel Cronbach Alfa değeri 0.913 'dür. Bu sonuca göre ankette yer alan önermelerin işaret ettiği faktörlerin konuyu çok yüksek derecede açıkladığını ortaya koymaktadır. Genel, faktör ve madde bazında Cronbach Alfa değerleri de tutarlılık göstermektedir (Tablo 2). 16 önerme için genel soru ortalaması (item-means) 4,323 ve ortalama varyans 0.877 'dir. Faktörler içerdikleri önermeler göz önüne alınarak isimlendirme yapılmıştır: Bu çerçevede faktörler ve isimleri; f1: özlük hakları, f2: çalışanı destekleme I, f3:çalışanı destekleme II ve f4: çalışan ilişkileri şeklindedir (Tablo 2).

Tablo 2: Faktör Analizi ve Tanımlayıcı İstatistikler

\begin{tabular}{|c|c|c|c|c|c|c|c|}
\hline \multirow{2}{*}{ Önermeler } & \multirow{2}{*}{$\begin{array}{l}\text { Faktör } \\
\text { İsimleri }\end{array}$} & \multicolumn{4}{|c|}{ Faktörler } & Cronbach Alfa Skorları & \multirow{2}{*}{$\begin{array}{r}\bar{X} \pm S \\
\mathrm{~N}=103\end{array}$} \\
\hline & & f1 & f2 & f3 & f4 & Genel $=0,913$ & \\
\hline Yeterli ücret düzeyi sağlanması & & ,788 & ,233 & ,221 & ,122 & ,738 & $4,4 \pm, 81$ \\
\hline Yeterli ücret artışı sağlanması & & ,775 & 247 & ,352 & ,042 & ,749 & $4,3 \pm, 83$ \\
\hline $\begin{array}{l}\text { Yeterli yan ödeme (yemek, ulaşım } \\
\text { vb.) sağlanması }\end{array}$ & $\begin{array}{l}\text { Ozluk } \\
\text { Hakları }\end{array}$ & ,728 & 112 & ,020 & ,441 & 779 & $4,4 \pm, 88$ \\
\hline $\begin{array}{l}\text { İzin ve tatil olanağının sağlanması } \\
\text { (yasal düzenleme dışında) }\end{array}$ & & ,495 & 369 & ,183 & ,323 & 812 & $4,1 \pm 1,04$ \\
\hline $\begin{array}{l}\text { Yetki ve sorumluluk denkliğinin } \\
\text { sağlanması }\end{array}$ & & 132 & ,736 &, 074 & 311 & 725 & $4,2 \pm, 92$ \\
\hline $\begin{array}{l}\text { İnisiyatif (işle ilgili karar verme } \\
\text { olanağı) sağlanması }\end{array}$ & Çalışanı & ,244 & 668 & ,312 &,- 078 & ,757 & $4,3 \pm 1,00$ \\
\hline $\begin{array}{l}\text { Maddi ve manevi (takdir, } \\
\text { onurlandırma vb.) ödül sağlanması }\end{array}$ & $\begin{array}{c}\text { Destekleme } \\
\text { । }\end{array}$ & ,219 & ,656 & ,423 & ,017 & ,747 & $4,2 \pm 1,10$ \\
\hline Amaç birliği sağlanması & & 315 & ,606 & 192 & ,260 & 729 & $4,2 \pm, 84$ \\
\hline Saygılı davranılmasının sağlanması & & ,274 & ,503 &,- 061 & ,486 & ,781 & $4,5 \pm, 72$ \\
\hline $\begin{array}{l}\text { Mesleki eğitim ve gelişim olanağı } \\
\text { sağlanması }\end{array}$ & Çalışanı & ,074 & 201 & ,787 & ,219 & ,717 & $4,3 \pm, 87$ \\
\hline $\begin{array}{l}\text { Uygun liderliğin (destek, güven, } \\
\text { stresi düşürme, yöneltme vb.) } \\
\text { sağlanması }\end{array}$ & $\begin{array}{c}\text { Destekleme } \\
\text { II }\end{array}$ & ,375 & ,216 & 716 & 129 & 645 & $4,3 \pm, 89$ \\
\hline
\end{tabular}




\begin{tabular}{|c|c|c|c|c|c|c|c|c|}
\hline $\begin{array}{l}\text { Yüksek performansa ek / daha fazla } \\
\text { ücret (prim) sağlanması }\end{array}$ & & ,477 & 321 & ,579 & ,091 & 750 & & $4,0 \pm 1,21$ \\
\hline $\begin{array}{l}\text { Çalışan sağ|ığı ve iş güvenliği } \\
\text { sağlanması }\end{array}$ & & ,244 & ,102 & 101 & ,757 & ,681 & \multirow{4}{*}{ 774 } & $4,4 \pm, 83$ \\
\hline $\begin{array}{l}\text { İletişim süreçlerinin etkinliğinin } \\
\text { sağlanması }\end{array}$ & Çalışan & ,286 &,- 042 & 470 & ,599 & 676 & & $4,2 \pm 1,01$ \\
\hline $\begin{array}{l}\text { Çalışan ilişkilerinin iyileştirilmesinin } \\
\text { sağlanması }\end{array}$ & İlişkileri &,- 106 & 475 & 296 & ,588 & 700 & & $4,3 \pm, 87$ \\
\hline $\begin{array}{l}\text { Fikirlere önem verilmesinin } \\
\text { sağlanması (katılımcı olma) }\end{array}$ & & ,116 & 279 & ,459 & ,479 & ,684 & & $4,3 \pm, 96$ \\
\hline
\end{tabular}

\subsection{Faktörlere Yönelik Bulgular}

Optisyenlik mağazaları çalışanlarının tek örnek t testi sonuçlarına göre iş motivasyonunu pozitif düzeyde etkilemede her bir faktörü ve genel faktörü ileri düzeyde önemsedikleri belirlenmiştir (Tablo 3). $\mathbf{H}_{\mathbf{1}}$ hipotezi (Optik mağazalarında ... faktörü iş motivasyonunu etkilemede pozitif yönde etkilidir) her bir faktör ve genel faktör için kabul edilmiştir.

Tablo 3: Faktörlere Yönelik Tek Örnek T Testi

\begin{tabular}{|c|c|c|c|c|}
\hline \multirow[t]{2}{*}{ Faktörler } & \multirow[t]{2}{*}{$\mathbf{N}$} & \multirow[t]{2}{*}{$\bar{x} \pm s$} & \multicolumn{2}{|c|}{$\begin{array}{l}\text { Tek Örnek } t \text { testi } \\
(\text { Test Değeri } 3 \leq \mu)\end{array}$} \\
\hline & & & $\mathbf{t}$ & $\mathbf{p}$ \\
\hline f1 (özlük hakları) & 103 & $4,3 \pm, 72$ & 19,221 & 000 \\
\hline f2 (çalışanı destekleme I) & 103 & $4,3 \pm, 68$ & 19,455 & ,000 \\
\hline f3 (çalışanı destekleme II) & 103 & $4,2 \pm, 83$ & 15,463 & ,000 \\
\hline f4 (çalışan ilişkileri) & 103 & $4,3 \pm, 69$ & 19,360 & ,000 \\
\hline f genel & 103 & $4,3 \pm, 62$ & 21,549 & ,000 \\
\hline
\end{tabular}

Çalışanı destekleme I, çalışanı destekleme II, çalışan ilişkileri ve genel faktör kapsamında $\mathbf{H}_{\mathbf{2}}$ hipotezi (Optik mağazalarında ... faktörü açısından iş motivasyonunu etkilemede optisyenlik bölümü mezunları ile meslek içinden gelenler arasında algı farklılığı vardır.) kabul edilmiştir. Optisyenlik bölümü mezunları sözü edilen faktörlerin iş motivasyonunu daha fazla pozitif yönde etkilediğini düşünmektedir (Tablo 4).

Tablo 4: Faktörlere Yönelik Bağımsız İki Örnek T Testi

\begin{tabular}{lccccc}
\hline \multicolumn{1}{c}{ Faktörler } & Personel & N & $\bar{x} \pm s$ & $\begin{array}{c}\text { Bağımsız İki Örnek } \\
\text { t Testi }\end{array}$ \\
& & & & t & p \\
\hline f1 (özlük hakları) & Opt. Böl. Mez. & 30 & $4,5 \pm, 64$ & 1,206 &, 230 \\
& Meslek iç. Gelme & 73 & $4,3 \pm, 74$ & & \\
f2 (çalışanı destekleme I) & Opt. Böl. Mez. & 30 & $4,5 \pm, 54$ & 2,178 &, 032 \\
& Meslek İç. Gelme & 73 & $4,2 \pm, 72$ & & \\
f3 (çalışanı destekleme II) & Opt. Böl. Mez. & 30 & $4,6 \pm, 55$ & 2,562 & \multirow{2}{*}{012} \\
& Meslek İç. Gelme & 73 & $4,1 \pm, 90$ & & \\
f4 (çalışan ilişkileri) & Opt. Böl. Mez. & 30 & $4,5 \pm, 60$ & 2,114 &, 039 \\
& Meslek iç. Gelme & 73 & $4,2 \pm, 71$ & & \\
f genel & Opt. Böl. Mez. & 30 & $4,5 \pm, 49$ & 2,375 &, 019 \\
\hline
\end{tabular}

Basit doğrusal korelasyon analizine göre; optik mağazası çalışanlarının algıları kapsamında iş motivasyonunu pozitif yönde etkilemeye yönelik olarak faktörlerin birlikte değişimleri / ilişkisellikleri pozitif yönde ileri düzeyde anlamlı bulunmuştur (Tablo 5). $\mathbf{H}_{\mathbf{3}}$ (Optik mağazalarında iş motivasyonunu pozitif yönde etkileme kapsamında faktörleri arasında pozitif yönde doğrusal bir ilişki vardır.) hipotez faktörlerin her birlikte değişim / iliş̧isellik için kabul edilmiştir. Faktör arasındaki ilişkiselliğin gücü orta-yüksek seviyededir. 
Tablo 5: Faktörlere Yönelik Korelasyon Analizi Bulguları

\begin{tabular}{|c|c|c|c|c|}
\hline Faktör & İstatistik & f1 & f2 & f3 \\
\hline \multirow{2}{*}{ f1 (özlük hakları) } & $r$ & & & \\
\hline & $p$ & & & \\
\hline \multirow{2}{*}{ f2 (çalışanı destekleme I) } & $r$ &, $648^{* *}$ & & \\
\hline & $p$ & ,000 & & \\
\hline \multirow{2}{*}{ f3 (çalışanı destekleme II) } & r &, $644^{* *}$ &, $643^{* *}$ & \\
\hline & $p$ & ,000 & ,000 & \\
\hline \multirow{2}{*}{ f4 (çalışan ilişkileri) } & r &, $580^{* *}$ &, $597^{* *}$ &, $606^{* *}$ \\
\hline & $p$ & ,000 & ,000 & ,000 \\
\hline
\end{tabular}

\section{SONUÇ}

Araştırma kapsamında optik mağazası çalışanlarının genel olarak iş motivasyonu algılarının yüksek düzeyde olduğu belirlenmiştir. Diğer taraftan işteki motivasyon algısının meslek içinden gelen çalışanlarda optisyenlik bölümü mezunu çalışanlara göre daha yüksek olduğu ortaya çıkmıştır. Perakende optik sektöründe meslek içinden gelen personel araştırmada da ortaya konduğu üzere, optisyenlere göre daha fazla çalışma süresine sahiptir. Bu nedenle meslek içinden gelen personelin çalıştığı sektörü ve yaptığı işi daha fazla benimsediği bunun sonucunda da motivasyon düzeyleri algılarının daha yüksek düzeyde ifade edildiği düşünülmektedir.

Optisyenlik mağazası çalışanlarınca özlük hakları bağlamında "yeterli ücret düzeyi, ücret artışı, yan ödeme ve izin/tatil olanağı"; çalışana destek I bağlamında "yetki ve sorumluluk denkliği, inisiyatif verilmesi, maddi ve manevi ödül, amaç birliği ve saygılı davranışın"; çalışana destek II bağlamında "mesleki eğitim ve gelişim, uygun liderlik ve yüksek performansa ek ücret (prim)"; çalışan ilişkileri bağlamında çalışan sağlığı ve iş güvenliği, iletişim süreçlerinin etkinliğinin, çalışan ilişkilerinin iyileştirilmesinin ve fikirlere önem verilmesinin (katılımcılı̆̆ın)" sağlanmasının iş motivasyonunu artırmada ileri düzeyde önemsendiği belirlenmiştir. Özdemir ve Muradova'nın (2008:151) çalışmasında da belirtildiği gibi personele önem vermek, yetki ve sorumluluklarını arttırmak, özgür iş ortamı oluşturmak çağdaş yönetimde verimliliğin temelidir.

Optisyenlik bölümü mezunları, meslek içinden gelen personele göre çalışana destek I, çalışana destek II ve çalışan ilişkileri bağlamında iş motivasyonunu arttırmadaki etkinin daha yüksek olduğunu düşünmektedirler. Ancak özlük hakları bağlamında algı farklılı̆ı ortaya çıkmamıştır. Optisyenlik bölümü mezunları alanlarıyla ilgili nitelikli personel olduklarını düşünmektedirler ve Herzberg'in çift faktör teorisine uygun olarak özlük hakları faktörü altında belirtilen olanakların sağlanmasının motivasyon arttırıcı faktör olmaktansa, bir işyerinde bulunması gereken imkanlar olarak değerlendirdikleri düşünülmektedir. Bir çok işyerinde benzer özlük haklara ve maddi olanaklara sahip nitelikli personel için daha çok manevi motivasyon araçları (taktir, teşvik, aidiyet, güvenlik) ya da farklı yönetsel uygulamalar (amaç birliği, yetki denkliği, gelişim olanağı sağlanması) iş performansını arttırıcı etkiye sahip olmaktadır (Filiz, 2004).

Diğer taraftan özlük hakları, çalışana destek I, çalışana destek II ve çalışan ilişkilerinin birlikte de optisyenlik mağazalarında iş motivasyonunu pozitif yönde etkiledikleri belirlenmiştir. Bu bağlamda etkileşim orta-yüksek düzeydedir. Dolayısıyla her bir faktörün beraberce değerlendirilerek de iş motivasyonunu artırıcı etkisi olacağı yargısı belirtilebilir.

Bu çalışma ile aşağıdaki çıkarsama ve yorumlar ortaya konulabilir:

i. Hem optisyenlik bölümü mezunu hem de meslek içinden gelen optik mağazası çalışanlarının iş motivasyonu artırmada bilinç düzeylerinin olumlu bir kapsamda olduğu belirlenmiştir.

ii. Optisyenlik bölümü mezunlarının motivasyonu artırmada rutin olmayan (çalışana destek ve çalışan ilişkileri) bağlamı daha fazla önemsedikleri ortaya çıkmıştır.

iii. Araştırma ile bilimsel olarak literatüre katkı sağlanmıştır. 
iv. Bu çalışma metropol olan İzmir ili kapsamında gerçekleştirildiği için Türkiye genelini temsil edebilecek sonuçları içermektedir.

\section{KAYNAKLAR}

EGOF, 2014 Ege Gözlükçüler ve Optisyenler Federasyonu, Kişisel görüşme-kasım 2014

Eren E, 2001. Yönetim Psikolojisi, 4. Baskı, Beta Yayınları, İstanbul

Eren, H., 1997. Toplam Kalite ve İnsan Kaynakları Yönetimi, 2.Baskı, Alfa Yayınları, İstanbul, s:97.

Eroğlu, F., 1995. Davranış Bilimleri, 2.B., Beta Yayınları, Ekim, İstanbul, s.247

Filiz, A., 2004. "Motivasyon ile Verimliliğin Yükseltilmesi”, Sektörel Tanıtım Dergisi, Eylül, 2004, s. 21.

Genç, N., 1990. "Kamu ve Özel Sektör Yöneticilerinin Astların Motivasyonu Açısından Degerlendirilmesi”, Atatürk Üniversitesi S.B.E. Doktora Tezi

Kaplan, M. 2007. "Motivasyon Teorileri Kapsamında Uygulanan Özendirme Araçlarının İşgören Performansına Etkisi Ve Bir Uygulama”, Atılım Üniversitesi Sosyal Bilimler Enstitüsü İşletme Ana Bilim Dalı yayınlanmamış Yüksek Lisans Tezi

Karakaya A., Alper Ay F. 2007, "Çalışanların Motivasyonunu Etkileyen Faktörler: Sağlık Çalışanlarına Yönelik Bir Araştırma”, C.Ü. Sosyal Bilimler Dergisi Mayıs Cilt : 31, no:1, s: 55-67

Koçel T, (2001)iş̧letme Yöneticiliği, Beta A.Ş., 8.Baskı, İstanbul, s. 154.

Koçel T. (2005) İşletme Yöneticiliği, Arıkan Yayınları,10.Baskı. Yayın No: 45 s.244-650.

Özdemir, S. 2008. “ỉş hayatında Motivasyon Problemlerine Çözüm Önerisi: İhtiyaç ve İsteklerin Farkındalığı Yaklaşımı”, s. 9.. Orta Asya ve Kazakistanın Ekonomisinin Modernizasyonu Uluslararası Konferansı, Almatı, 2008.

Özdemir S., Muradova T. 2008, Örgütlerde Motivasyon Ve Verimlilik İlişkisi Journal of Qafqaz University sayı 24, s.146-153 